Puede citar este artículo como:

Brown, Michael. «Realms, regions and lords: Ireland and Scotland in the later Middle Ages». Anales de la Universidad de Alicante. Historia Medieval, N. 19 (2015-2016): 153-174, DOI:10.14198/ medieval.2015-2016.19.05

\title{
REALMS, REGIONS AND LORDS: IRELAND AND SCOTLAND IN THE LATER MIDDLE AGES
}

\author{
Michael Brown \\ Department of Scottish History, University of St Andrews
}

\section{RESUMEN}

Los estudios sobre política de las Islas Británicas en la baja edad media han tendido a tratar sobre territorios concretos o a poner el Reino de Inglaterra en el centro de los debates. No obstante, en términos de su tamaño y carácter interno, hay buenas razones para considerar el Reino de Escocia y el Señorío de Irlanda como modelos de sociedad política. Más allá las significativas diferencias en el estatus, leyes y relaciones externas, hacia el año 1400 los dos territorios pueden relacionarse por compartir experiencias comunes de gobierno y de guerras internas. Éstas son las más aparentes desde una perspectiva regional. Tanto Irlanda y Escocia operaban como sistemas políticos regionalizados en los que predominaban los intereses de las principales casas aristocráticas. La importancia de dichas casas fue reconocida tanto internamente como por el gobierno real. Observando en regiones paralelas, Munster y el nordeste de Escocia, es posible identificar rasgos comparables y diferencias de largo término en dichas sociedades.

Palabras clave: Baja edad media; Escocia; Irlanda; Guerra; Gobierno.

\section{ABSTRACT}

Studies of the polities of the British Isles in the later middle ages have tended to deal with the individual lands or to place the English kingdom at the centre of discussions. However, in terms of their size and internal character there are good reasons for considering the Scottish kingdom and the lordship of Ireland as models of political society. Beneath the significant 
differences of status, law and external relationships, around 1400 the two lands can be regarded as sharing common experiences of government and internal warfare. These are most apparent from a regional perspective. Both Ireland and Scotland operated as regionalised polities in which the interests of major aristocratic houses predominated. The importance of such houses was recognised both internally and by the royal government. By looking at parallel regions, Munster and north-east Scotland, it is possible to identify comparable features and long-term differences between these societies.

Keywords: Late Medieval; Scotland; Ireland; War; Government.

In the winter of 1306-7 Robert Bruce king of Scots sent letters to the kings, clergy and inhabitants of Ireland. He wrote that «our people and yours ... arise from one branch of a nation as much by a common language as by ancient customs which call forth a friendly spirit». Robert wrote seeking assistance against the English king. Both the Scots and the Irish were reportedly fighting this common English enemy so that «our ancient nation can be restored to freedom ${ }^{1}$. Robert Bruce was referring to the well-known kinship of the two peoples. In the myths which they told about their origins as a nation, the Scots traced their roots back to the Gael of Ireland. In the early medieval period, the political, religious, linguistic and cultural links between Ireland and Scotland represented a major theme of their historiography ${ }^{2}$. After 1100 such links seemed less important. The impact of Norman and English conquest had the effect of fragmenting and diminishing the Gaelic world. Ireland, which was bestowed by a Papal grant on Henry II of England was thereafter claimed as a lordship which was treated as an inalienable property of the English crown. The conquest and colonisation of many parts of Ireland, especially in the east and south, reduced the power and status of native Irish elites ${ }^{3}$. Scotland continued to be ruled by a single, native royal dynasty. However its government, church and society were transformed by

1 Duffy, S., «The Bruce Brothers and the Irish Sea World, 1306-1329», Cambridge Medieval Celtic Studies, 21 (1991), pp. 55-86; S. Duffy, Robert the Bruce's Irish Wars: The Invasions of Ireland 1306-1329, Stroud, 2002.

2 Broun, D., The Irish Identity of the Kingdom of Scots in the Twelfth and Thirteenth Centuries, Woodbridge, 1997; Fraser, J., Caledonia to Pictland: Scotland to 795, Edinburgh, 2009; Woolf, A., From Pictland to Alba 789-1070, Edinburgh, 2007.

3 Lydon, J., The Lordship of Ireland in the Middle Ages, Dublin, 2003; Lydon, J. «Ireland and the English Crown, 1171-1541», Irish Historical Studies, 115 (1995), pp. 281-94; Frame, R., Colonial Ireland 1169-1369, Dublin, 2012; Flanagan, M.T., Irish Society, Anglo-Norman Settlers, Angevin Kingship: Interactions in Ireland in the late twelfth century, Oxford, 1989. 
the enthusiasm of these rulers for the mechanisms and personnel employed in the Anglo-Norman realm or more widely on the European continent ${ }^{4}$.

This change has influenced the way late Medieval Scotland and Ireland have been regarded. Though the continued existence of a common Gaelic world spanning both lands into the fourteenth and fifteenth century is recognised, discussion has revolved primarily around the fascinating entity which was the Lordship of the Isles ${ }^{5}$. More broadly-based consideration of these two lands as comparable realms and polities between 1300 and 1500 has been very rare. Discussions of the different lands of the British Isles in the later middle ages have instead been based on relationships and comparisons which make England the central focus. This is a product of the size and sophistication of the English realm and its influence on insular neighbours after 1100 and a reflection of the sheer weight of historiography which is well beyond anything available for the other lands of the British Isles. The inevitable consequence of this has been to create comparisons between England, a large and economically-developed society with a highly integrated and homogenous polity, with lands of internal diversity where government and political direction had always possessed a strong regional basis. This has led to the so-called 'Celtic' lands being seen as underdeveloped and backward ${ }^{6}$.

This view has been greatly modified by research since the 1970s which has judged each land in terms of its own character and historical development. In the same period fresh perspectives have also been developed which have sought to integrate the different parts of the British Isles as a unit of political geography in different periods ${ }^{7}$. For obvious reasons, England has retained the central place in these discussions. There has been no direct attempt to draw comparisons in which England is not the major component. This article is an exercise in examining government and political society in Scotland

4 Oram, R., Domination and Lordship: Scotland 1070-1230, Edinburgh, 2011; Duncan, A.A.M., Scotland: The Making of the Kingdom, Edinburgh, 1975.

5 Boardman, S., «The lost world: post-medieval accounts of the lordship of the Isles», in Duffy S. and Foran S., The English Isles: Cultural Transmission and political conflict in Britain and Ireland, 1100-1500, Dublin, 2013, pp. 151-74; McLeod, W., Divided Gaels: Gaelic cultural identities in Scotland and Ireland,c.1200-c.1650; Ellis, S.G., «The collapse of the Gaelic World, 1450-1650», Irish Historical Studies, 31 (1998-9), 449-69.

6 Barrow, G.W.S., Feudal Britain, The completion of the Medieval Kingdoms, 1066-1314, London, 1956; Otway-Ruthven, A.J., A History of Medieval Ireland, London, 1980.

7 Frame, R., The Political Development of the British Isles, Oxford, 1990; Ellis, S.G., Tudor Frontiers and Noble Power: The Making of the British State, Oxford, 1995; Davies, R.R., Domination and Conquest: The Experience of Ireland, Scotland and Wales, 1100-1300, Cambridge, 1990. 
and Ireland as a means of highlighting their defining characteristics in the century and a half after 1300. The two lands are roughly equivalent in size. Their late Medieval character involved similar economic development and internal diversity based on the existence of populations of both English and Gaelic speech.

However any such approaches have been discouraged by the obvious and major differences between these two medieval realms in terms of their status and internal identities. Most clearly, Scotland was a unitary kingdom, sovereign and separate from other polities. Its line of kings and the institution of kingship were regarded in historical narratives as defining features of Scottish identity, providing a present and personal focus for the unity of the realm, its government and the idea of Scotland ${ }^{8}$. The lordship of Ireland lacked the key element of personal monarchy. The late medieval lordship of Ireland was one of the dominions held by the kings of England. It was administered in the name of the English king, but not in person. Between 1210 and Richard Il's expeditions of 1394-5 and 1399, no English king spent time in his Irish lordship. Since the twelfth century royal rights had been exercised by an administration headed by a lieutenant, but ultimate authority in the lordship lay outside Ireland at the English king's court ${ }^{9}$.

The exercise of this authority was also shaped by the division of the inhabitants of the island into English and Irish. From the thirteenth century the English administration sought to sharpen the distinctions between these two races in terms of legal status, familial bonds and social behaviour through legislation. The best-known example of this approach are the statutes of Kilkenny from $1366^{10}$. Such attitudes placed the Irish outside or on the fringes of the English king's lordship. Irish lords might seek the recognition or protection of the crown and its officials for their status and property but experience had taught them their vulnerability to dispossession and death at English hands ${ }^{11}$. While the Irish tended to be characterised in the lordship's records as enemies and rebels, the

8 Broun, D, Scottish Independence and the Idea of Britain: From the Picts to Alexander III, Edinburgh, 2007.

9 Otway-Ruthven, History of Medieval Ireland, 144-90; Frame, R., English Lordship in Ireland 1318-1361, Oxford, 1981, 1-10, 75-123, 197-202.

10 Irish Historical Documents 1172-1922, ed. E. Curtis and R.B. McDowell, London, 1943, no. 17; Duffy, S., "The problem of degeneracy», in Lydon, J., Law and Disorder in Thirteenth-Century Ireland, Dublin, 1997, pp. 87-106.

11 See for example Frame, R., "The Justiciar and the Murder of the MacMurroughs in 1282», in Frame, R., Ireland and Britain 1170-1450, London, 1998, pp. 241-48. 
English inhabitants of Ireland were termed 'loyal' and 'peaceful'12. Though there has been a strand of historical writing which regarded them as an Anglo-Irish «middle people», they wrote to the king as «your English liege people», defined in terms of race by history, language and institutions ${ }^{13}$. If connections of land and family with England declined in scale after 1300, the English nobility of Ireland were still regularly in contact with their king and their English peers. The outlook of English officialdom in Ireland was expressed in terms of a notional, single struggle with the Irish enemy. The goals of this war were, from an English perspective, conquest or, more realistically, the defence of the king's lordship which was seen as being in danger of total collapse ${ }^{14}$.

Though the reality behind such statements could be very different, these perceptions represent a major contrast with late medieval Scotland. There is plenty of evidence that, in the later fourteenth century, Scots had a sense of themselves as a single nation defined by common allegiance and historical experience. This experience had been sharpened by the war with England, at its most intense between 1296 and 1357 but continuing through the rest of the fourteenth and most of the fifteenth centuries without a formal peace. Shared service in this war and memories of individual and collective participation in a struggle to defend «the liberty of the land» against English tyranny was enshrined in historical works like John Barbour's epic poem, The Bruce, or the chronicles attributed to John of Fordun and Walter Bower ${ }^{15}$. The language of the communitas regni, found in many European realms from the thirteenth century, has been regarded by modern historians as both a theoretical and applied base for collective action by Scots from the 1280s and an element in a conscious national identity ${ }^{16}$. This was heightened further by the severing of many cross-border ties with England as a consequence of the

12 There was a growing category of 'English rebels', families who were unresponsive to the demands of the royal government and increasingly enmeshed with Irish lords and kindreds.

13 Lydon, J, «'The Middle Nation'», in J. Lydon, The English in Medieval Ireland, London, 1984, pp. 1-26.

14 Statutes, Ordinances and Acts of the Parliament of Ireland: King John to Henry V, ed. H.F. Berry, Dublin, 1907, pp. 342-6; Frame, R., «War and peace in the Medieval Lordship of Ireland», in Lydon, English in Medieval Ireland, pp. 118-41.

15 Barbour, John, The Bruce, ed. A.A.M. Duncan, Edinburgh, 1996; Bower, Walter, Scotichronicon, ed. D.E.R. Watt, 9 vols, Aberdeen and Edinburgh, 1987-1998; Fordun, John de, Chronica Gentis Scotorum, ed. W.F. Skene, 2 vols, Edinburgh, 1871-2.

16 Barrow, G.W.S., Robert Bruce and the Community of the Realm of Scotland, Edinburgh, 2005; Duncan, A.A.M., The Nation of Scots and the Declaration of Arbroath, London, 1970. 
conflict. This created an aristocracy which by 1400 was exclusively Scottish in terms of landholding and allegiance ${ }^{17}$.

If these characteristics marked a clear difference from fourteenth-century Ireland, there is evidence of a comparable internal divergence. In a range of sources from the 1360s onwards groups from eastern and southern Scotland identified the inhabitants of the Highlands and Western Isles as a distinct community. Fordun's Chronica Gentis Scotorum talks of «two types of Scots» distinguished by language, dress and regard for peace and the law. ${ }^{18}$ The association of the Highlands and Isles with violent lawlessness was also present in parliamentary legislation from the 1360s onwards and later writers like Andrew Wyntoun and Walter Bower depict the Islesmen and Highlanders as fearsome warriors and plunderers, "wylde wickyt Helande men». Such language echoes English descriptions of native Irish but the inhabitants of the Highlands were still regarded as Scots. Their use of «the Scottish tongue», Gaelic, led Wyntoun to identify them as «Scottis men» in an account of a fight with lowlanders. Terms like «our fellow Scots beyond the mountains» or, more pejoratively, «wild scottys» distinguished by geography and behaviour rather than ethnicity. Despite the antagonistic tone of these lowland sources, there is none of the legal separation of the realm between two races which existed in contemporary Ireland ${ }^{19}$.

However expressions of a sense of internal divergence between lowland and Highland Scots are an indication that during the century from 1280 there had been changes in both Ireland and Scotland which produced apparent similarities. One aspect of this lay in the way in which the two polities drew on and adapted English approaches to government. This process had been underway since the twelfth century but the fourteenth century produced interesting developments. By 1400 in the lordship of Ireland and in the Scottish kingdom there were mechanisms for rule by individuals who had been given authority as deputies or lieutenants of the king. This had developed in different ways. In the lordship of Ireland the employment of a justiciar was a response to the almost permanent absence of the king since the $1170 \mathrm{~s}^{20}$. In Scotland, the appointment of vice-regal figures was more

17 Brown, M., Disunited Kingdoms: Peoples and Politics in the British Isles 1280-1460, London, 2013, pp. 149-52; Davies, R.R., Lords and Lordship in the British Isles in the Late Middle Ages, Oxford, 2009.

18 Fordun, Chronica Gentis Scotorum, i, p. 38.

19 Bower, Scotichronicon, viii, 267; Wyntoun, Andrew of, The Original Chronicle of Andrew Wyntoun, ed. Amours, FJ., 6 vols, Edinburgh, 1903-14, vi, pp. 368, 371-5.

20 Otway-Ruthven, A.J., "The chief governors of Medieval Ireland», in Crooks, P., Government, War and Society in Medieval Ireland, Dublin, 2008, pp. 79-89. 
recent and developed out of the repeated crises since 1286 which had made the absence of an effective king the norm in the next century. The frequency of these absences led to lieutenancy being employed as a means of side-lining adult kings who had been accused of providing ineffective rule from the 1380s. The single guardians and lieutenants who ran the Scottish realm for much of the 1330s, 1340s, 1350s, and from 1384 onwards performed similar roles to the justiciars and lieutenants of Ireland ${ }^{21}$.

Such similarities reflect, above all, the needs and expectations of government in medieval polities. The nature of Scottish and Irish lieutenancies was, in reality, distinguished by the choice of individual officers. After the 1330s Scottish guardians and lieutenants, were from the close royal circle and in the 1380s and 1390s were the king's sons or brother and great magnates ${ }^{22}$. Aside from Edward III's son, Lionel duke of Clarence, and his heirs as earl of Ulster, the Mortimers, Irish justiciars were great Anglo-Irish magnates or relatively minor knights sent by the king from England ${ }^{23}$. The result of these interventions produced tensions between English and Irish (in this case the English of Ireland) of a type absent from Scotland. The resulting politics was played out in different arenas, in Irish provinces, at the central courts in Dublin or at Westminster before an absent, but well-informed, English king ${ }^{24}$. Whilst lacking this wide framework, the politics of Scottish lieutenancy in the 1380s and 1400s could produce similar competition for this office as found in Ireland after 1414 as a means of building influence in each realm ${ }^{25}$. Amongst the charges in this case was Talbot's claim that Ormond used his office to reward his own friends and enlarge his interests. Similar connections between the public responsibilities of guardianship and

21 Reid, N., «The kingless kingdom: The Scottish guardianships of 1286-1306», Scottish Historical Review, 61 (1982), pp. 105-29; Penman, M., David II 1329-71, East Linton, 2004; Boardman, S., The Early Stewart Kings: Robert II and Robert III, East Linton, 1996.

22 Boardman, Early Stewart Kings, pp. 6, 8, 130-2, 151-3.

23 Crooks, P., «'Hobbes', 'Dogs' and Politics in the Ireland of Lionel of Antwerp, c. 1361-6», The Haskins Society Journal, 16 (2005), pp. 117-48; Tuck, J.A., «Anglo-Irish Relations, 1382-1393», Royal Irish Academy Proceedings, 69 (1970), pp. 15-31; Frame, English Lordship in Ireland, 87-98, 260-64, 307-12.

24 Hartland, B., «Edward I and Petitions relating to Ireland», in Prestwich, M., Britnell, R., and Frame, R., Thirteenth Century England, ix (2003), pp. 59-70; Frame, English Lordship in Ireland, 106-23.

25 Boardman, Early Stewart Kings, 233-47; Griffiths, M., «The Talbot-Ormond Struggle for control of the Anglo-Irish government, 1414-1447», Irish Historical Studies, 8 (1941), pp. 376-97; E.A.E. Matthew, «The governing of the Lancastrian lordship of Ireland in the time of James Butler fourth earl of Ormond c. 1420-52», unpublished PhD thesis, Durham, 1994, pp. 106-227. 
the private ends of individual guardians were a recurring theme of Scottish political life. The employment of figures who exercised royal authority via its temporary delegation in both lands was partly responsible for the blurred distinction between royal government and aristocratic lordship which was a strong feature of their political characters in the later middle ages.

Though both the Irish and Scottish lieutenancies grew from the justiciarship of twelfth-century England, in the fourteenth century the use of these offices distinguished the governing of these realms from that of England. The development of parliamentary assemblies in Ireland and Scotland was similarly derived from English models. This relationship was closer in terms of chronology and structure. Both the Scottish and Irish parliaments took an identifiable form in the last decade of the thirteenth century ${ }^{26}$. These gatherings consciously followed the parliament of England. However, during the next century, the lack of a clear distinction between parliaments and councils and the absence of a distinct Commons suggest that Irish and Scottish assemblies remained less formalised than the English body ${ }^{27}$.

The informality and political character of Irish and Scottish parliaments were products of the size and nature of the wider polity. They reflected societies in which the scale and reach of royal government was more limited than in England and where dialogue between crown and subjects did not overshadow all other forms and arenas. Parliaments in Scotland and Ireland did operate as the most formal source of communal consent. They also functioned as a forum for the expression of criticism and even resistance to royal policy. David II of Scotland's plans to name an English heir to his throne in 1364 were rejected in a meeting of parliament, while the financial demands of the lieutenant, William Windsor, in the 1370s led to obstruction ${ }^{28}$. This

26 Duncan, A.A.M., «The Early Parliaments of Scotland», Scottish Historical Review, 45 (1966), pp. 36-58; MacQueen, A.B., 'Parliament, the Guardians and John Balliol, 1284-96', in Brown, K., and Tanner, R., The History of the Scottish Parliament I: Parliament and Politics in Scotland 1235-1560, Edinburgh, 2004, pp. 29-49; Lydon, J., «Ireland in 1297: 'At peace after its manner», in Lydon (ed.), Law and Disorder, pp. 11-24.

27 Brown, K., et al, Records of the Parliaments of Scotland, St Andrews, 2008 [consulted 10/4/2014]. http://www.rps.ac.uk/, 1342/2/1, 1362/1, 1365/7/1, 1367/9/1; Penman, M., «Parliament Lost - Parliament Regained? The Three Estates in the reign of David II, 1329-71», in Brown, K., and Tanner, R., The History of the Scottish Parliament, pp. 74-101; Richardson, H.G. and Sayles, G.O., The Irish Parliament in the Middle Ages, Philadelphia, 1952, pp. 57-100, 104-8.

28 Crooks, P., «Representation and dissent: 'Parliamentarianism' and the structure of politics in Colonial Ireland, c.1370-1420», English Historical Review, 125 (2010), pp. 1-34; Duncan, A.A.M., "A question about the succession, 1364», in Miscellany of the Scottish History Society, xii (Edinburgh, 1994), pp. 1-57. 
episode illustrates a further difference arising from the English king's absentee authority. While the communities opposed to Windsor's coercive approach in parliament had to take their complaints across the sea to Edward III's court, the Scots in parliament had more direct redress. It was at assemblies in 1384, 1388 and 1399 that lieutenants were appointed to stand in for incapable or incompetent kings ${ }^{29}$. In essence, however, the roles played by parliamentary bodies in Ireland and Scotland were directly comparable with those of the English parliament. At times the link seems very close. The use of parliament by James earl of Ormond and James I of Scotland in the 1420s as a means of demonstrating their good governance of the polity has been related to Henry V's management of the English body ${ }^{30}$. Despite Scotland's sovereignty, it is reasonable to see the three parliaments of the late Medieval British Isles as interrelated bodies.

There is a value in drawing such comparisons but central institutions are not the key to understanding either Ireland or Scotland in the later Middle Ages. While the search for a core political narrative based on events at a notional centre has preoccupied the historians of both countries, it has been recognised that in the late fourteenth and early fifteenth century the political character of the two lands was formed at a regional level ${ }^{31}$. The basis for these characters derived from geography and from history which, in different ways, fostered strong provincial traditions which continued to be influential. Since the twelfth century, grants of large private franchises, defined territories with powers of justice and fiscal rights, had been made to major nobles. For example in fourteenth-century Ireland, the liberties of Kerry, Tipperary and Kildare had been created for the English earls of Desmond, Ormond and Kildare ${ }^{32}$. In Scotland grants of regality were made to cover many of the ancient earldoms and major lordships like Galloway, enhancing the judicial

29 Boardman, S., «Coronations, Kings and Guardians: Politics, Parliaments and General Councils, 1371-1406» in Brown K. and Tanner R., The History of the Scottish Parliament, pp. 102-22.

30 Brown, M.H., «Public authority and factional conflict: Crown, parliament and polity, 1424-1455», in Brown, K., and Tanner, R., The History of the Scottish Parliament, pp. 123-44. Crooks, P., «Representation and dissent: 'Parliamentarianism' and the structure of politics in Colonial Ireland, c. 1370-1420», English Historical Review, 125 (2010), 1-34.

31 B. Smith, «The British Isles in the Late Middle Ages: Shaping the Regions», in Smith, B., (ed.), Ireland and the English World in the Late Middle Ages: Essays in Honour of Robin Frame (Basingstoke, 2009), 7-19; Watts, J., The Making of Polities: Europe, 13001500, Cambridge, 2009, 270-82.

32 Hartland, B., «The liberties of Ireland in the reign of Edward I», in Prestwich, M., Liberties and Identities in the Medieval British Isles, Woodbridge, 2008, pp. 200-16. 
rights attached to these established provinces ${ }^{33}$. The existence of large, private jurisdictions was an element in the regional character and the nature of aristocratic influence within a particular area but the regionalisation of government and politics was not confined to these franchises. In both Ireland and Scotland, this process related to the way polities operated and were held together as arenas for networks or conflicts, and the nature of their contact with royal government.

Over thirty years ago in his article «Power and Society in the Lordship of Ireland, 1272-1377» Robin Frame emphasised the importance of analysing the island in terms of such regional characteristics. He stressed the need to treat Ireland with regard to the varied expectations of different parts of the lordship rather than starting from the negative perspective of Westminster or Dublin. Ireland could be regarded as operating as a series of interlinked borderlands, internally and simplistically defined into lands of peace or war ${ }^{34}$. Even in eastern Leinster, which was the normal base for the royal government, there were lands of war in which issues of allegiance and obedience to royal justice were at stake. Though it was principally the justiciars who managed issues of war and peace directly in Leinster, the role of the head of the royal government was increasingly limited elsewhere ${ }^{35}$. There is a strong sense that the political and administrative characters of the other parts of Ireland were a product of regional and aristocratic dynamics. The late medieval experiences of Munster in the south-west, Connacht in the west, Ulster in the north and even in the western parts of Leinster and neighbouring Meath, derived much more from the competition or collaboration of major noble dynasties than from direct relations with the justiciars. In Ulster, the end of the de Burgh line of earls and the primacy they had sought to exercise in much of the province led to the ascendancy of Irish lords and 'rebel' English families, largely beyond the authority of royal officials in both Ulster and neighbouring Connacht. Though in Munster, the English earls of Ormond and Desmond

33 Grant, A., 'Franchises north of the border: Baronies and regalities in medieval Scotland', in Prestwich, Liberties and Identities, pp. 155-99.

34 Frame, R., «Power and Society in the Lordship of Ireland, 1272-1377», Past and Present, 26 (1977), pp. 3-33. See also Smith, B., Colonisation and Conquest in Medieval Ireland: The English in Louth, 1170-1330 Cambridge, 1999; Smith, B., Crisis and Survival in late Medieval Ireland: The English of Louth and their neighbours, 1330-1450, Oxford, 2013.

35 Frame, R., «English Officials and Irish Chiefs in the Fourteenth Century», English Historical Review, 90 (1975), pp. 748-77; Frame, R., Two Kings in Leinster: "The Crown and the MicMhurchadha in the Fourteenth Century», in T. Barry, R. Frame and K. Simms (eds), Colony and Frontier: Essays presented to J.F. Lydon, Dublin, 1995, pp. 155-76; O'Byrne, E., War, Politics and the Irish of Leinster, Dublin, 2003. 
were the most important figures, it was their relationships with each other and with regard to other Irish and English nobles and communities in the region which was most important in shaping the south-west. If Frame has subsequently indicated that he overemphasised the extent to which Ireland was «a patchwork of lordships», its identification as «a localized marcher society» remains convincing ${ }^{36}$.

Can Scotland be treated in the same way, as a heavily regionalised polity, where the key level of political action, if not political identity, was below that of crown and the community of the realm? This would run counter to traditional historiography which has stressed central politics. The war with England was a very different kind of conflict from warfare in Ireland both in military terms and in the ideology which sustained it. However, like Irish warfare, Anglo-Scottish fighting shaped regional society. By 1400 the southern-most sheriffdoms of Scotland had an internal character which was defined by periods of major warfare and by the continued presence of English garrisons within Scotland ${ }^{37}$. These features made effective war against English lordship a key issue in the area. By this period the leadership of this war and cross-border justice was in the hands of regional magnates, principally the earls of Douglas and March. These families held authority as march wardens. Nominally these were royal-appointed lieutenants as in England, but their position rested in reality on their resources as great nobles ${ }^{38}$. Regional politics was dominated by their relationship, as March's defection to England in 1400 after a dispute with the Douglases demonstrated. Royal direction in the marches worked through the wardens and their allies who could influence the exercise of royal authority, as in 1384 when Robert II's reluctance for war against England led to his being replaced by his son, Carrick, who was named lieutenant. By the early fifteenth century there are good reasons for seeing this border region extending north into Lothian, an area traditionally regarded as a core of the kingdom. As an indication of this after 1400 Archibald fourth earl of Douglas was justiciar of Lothian, keeper of Edinburgh Castle and had strong ties of lordship with local nobles ${ }^{39}$.

36 Frame, R., «Power and Society in the Lordship of Ireland, 1272-1377», in Frame, Ireland and Britain, 191-220, 219-20.

37 Brown, M., «War, Allegiance and Community in the Anglo-Scottish Marches: Teviotdale in the Fourteenth Century» in Northern History, 41 (2004), pp. 219-38.

38 Brown, M., «The Scottish March Wardenships c.1340- c.1480», in A. King and D. Simpkin, England and Scotland at War, c.1296-c.1513, Brill, 2012, pp. 203-30.

39 Brown, M., The Black Douglases: War and Lordship in Scotland 1306-1455, East Linton, 1998; Boardman, Early Stewart Kings, pp. 108-25, 228-32; Macdonald, A., Border Bloodshed, Scotland, England and France at War, 1369-1403, East Linton, 2000. 
The experience of southern Scotland as a region exposed to war with England made it exceptional within the Scottish realm and had transformed it since the late thirteenth century from a royal heartland to a frontier zone. Its distinct leadership persuaded one contemporary English account to say that «th'erlle Douglas (did) bothe governe and reule over this syde the Scottische see (the Firth of Forth)». The same source associated the rule of Scotland north of the Forth with Robert Stewart duke of Albany ${ }^{40}$. From 1402 until his death in 1420 Albany was lieutenant and then governor of Scotland during the incapacity of his brother, King Robert III, and then the English captivity of James I. Duke Robert was also a great lord, principally in central Scotland where he held the earldoms of Fife and Menteith and a family interest in neighbouring Lennox. Allied to this were extensive connections in other central and northern districts. The vast majority of his acts as governor were issued from centres between the Forth and the Grampians, suggesting an obvious overlap between Robert's authority as a regent and the areas in which he had major estates and a strong personal following. Fewer than $10 \%$ of these acts came from Edinburgh and in 1409 Albany concluded an indenture with the earl of Douglas which expressed the relations between the Albany and the earl in terms of private equality not between governor and subordinate ${ }^{41}$. Albany also seems to have accepted that the authority of the crown north of the Grampians was best exercised via the appointment of a lieutenant ${ }^{42}$. In both north and south, there is a strong sense that Albany worked with the grain of Scottish political society, acknowledging the existence of regional interests and networks which could be best directed internally.

This evidence of the development of regional frameworks for Scottish government and politics between 1370 and 1420 suggests comparisons with the lordship of Ireland. The nature of these comparisons requires an examination of how regional societies worked. In this respect it may be instructive to place south-western Ireland, the province of Munster, alongside north-eastern Scotland, the region from the Grampians northwards to the Moray Firth, the Great Glen and Ross. These two regions were broadly

40 Connolly, M., "The Dethe of the Kynge of Scotis: A new edition», Scottish Historical Review, 71 (1992), 46-69, 49-50.

${ }^{41}$ Hunt, K., «The governorship of Robert Duke of Albany, 1406-20», in M. Brown and R. Tanner (eds), Scottish Kingship 1306-1488: Essays in Honour of Norman Macdougall (Edinburgh, 2008), 126-54; P.G.B. McNeill and H.L. MacQueen (eds), Atlas of Scottish History to 1707, Edinburgh, 1996, p. 176; Brown, The Black Douglases, 110-11.

42 Brown, M., «Regional Lordship in North-East Scotland: The Badenoch Stewarts II: Alexander Stewart Earl of Mar», in Northern Scotland, 16 (1996), pp. 31-54, 39. 
similar in scale and represented a significant proportion of the whole land (between a quarter and a third). However, in the later Middle Ages both have tended to be regarded as removed from the core regions of royal government. It became increasingly unusual after 1350 for English justiciars, who were not magnates from the province, to come to Munster in person ${ }^{43}$. Similarly, in normal conditions, appearances by Scottish kings north of the Grampians were not routine events but reactions to specific circumstances. This treatment was clearly a product of geographical distance and of the physical features which lay between the normal centres of royal administrations and these regions. The line of the Grampians from Atholl to the Mounth running down towards the sea south of Aberdeen was regarded as a natural division in Medieval Scotland ${ }^{44}$. Less imposing but equally challenging for contact were the hills and bogs of Laois, Offaly and Ossory which lay between Dublin and Tipperary, Limerick and Cork.

However, neither north-eastern Scotland nor south-western Ireland can be treated as peripheral regions of wider lands. This was a product of their size, character and history. Both Munster and the north-east contained major centres. For example, Aberdeen was the second-most important town for the export of customable goods from late medieval Scotland while Waterford and Cork were second and third in similar terms in Ireland ${ }^{45}$. As this suggests, these centres provided direct contacts to other lands. Waterford and Cork had connections, not just to England, but also to Gascony, while Aberdeen had traded with the Low Countries, northern Germany and Scandinavia ${ }^{46}$. Moreover both regions played significant roles in wider events. During the 1330s and early 1340s the financial returns from the sheriffdoms of Aberdeen and Banff indicate that these northern lands provided the base for Scottish

43 The best description is Frame, R., «Lordship beyond the Pale: Munster in the later Middle Ages», in Stalley, R., Limerick and South-West Ireland: Medieval Art and Architecture, The British Archaeological Society Conference Transactions, 34, 2011, pp. 5-18.

44 Often described as being 'extra montem' or 'transmontani' (beyond the mountains) in Scottish sources (Bower, Scotichronicon, viii, pp. 266-7).

45 O'Brien, A.F., «Politics, Economy and Society: The development of Cork and the Irish south-coast region c. 1170 to c. 1583», O' Flanagan, P., and Buttimer, C.G., Cork, History and Society, Dublin, 1993, pp. 83-154; Dennison, E.P., Simpson, A.T. and Simpson, G.G., "The growth of two towns», Dennison, E.P., Ditchburn, D., and Lynch, M., Aberdeen before 1800: A New History, East Linton, 2002, pp. 13-43.

46 O'Brien, «Politics, Economy and Society», in O'Flanagan and Buttimer, Cork, History and Society, pp. 92, 96; «Late Medieval Ireland and the English Connection: Waterford and Bristol, ca 1360-1460», Journal of British Studies, 50 (2011), 546-65.

Jackson, G., «Aberdeen and the Sea», Dennison, Ditchburn, and Lynch, Aberdeen before 1800: A New History, pp. 159-80. 
governments opposing the rule of Edward III of England. The English of Munster had similarly supported the war against the Bruces in 1317 but their longer-term contribution to English government came via the roles played by the earls of Desmond and, more importantly, the earls of Ormond as justiciars ${ }^{47}$.

The two regions were characterised by major variations in the quality and use of land which shaped their social and political character. In Munster, areas of twelfth and thirteenth-century English settlement and arable production in east Cork, Tipperary and Waterford were bordered by poorer quality lands used primarily for grazing, especially in west Cork and Kerry which experienced very limited colonisation. There was similar variation in north-east Scotland between coastal lowlands from Aberdeenshire round to the Black Isle and Easter Ross and the Highland districts of Moray and Ross. These economic variations overlay differences of social and legal practice and of the predominant language between English or Anglicised populations and Irish or Gaelic inhabitants. As regions of mixed custom and language, physically removed from the normal centres of royal government but still highly significant, Munster and northeastern Scotland provide the basis for valid comparison.

Like other areas in Ireland and Scotland, both regions were defined by the activities and interests of leading magnate dynasties. In south-west Ireland, from the early fourteenth century this meant the earls of Desmond and Ormond, while in northern Scotland the holders of the earldoms of Mar, Moray and Ross and of the lordship of Badenoch were the principal regional figures. Their forceful efforts to extend their lordship, frequently in competition with neighbouring lords, were more important in forming the character of regional politics than the, essentially external and more sporadic, interventions by the royal government. Thus, in the 1320s and 1330s Maurice first earl of Desmond's efforts to secure greater property and influence from Thomond to Waterford drove a series of conflicts between the earl and his opponents ${ }^{48}$. From the mid-fourteenth century the rivalry between Desmond's successors and the earls of Ormond provided a source

47 The Exchequer Rolls of Scotland, ed. Stuart, J. and Burnett, G., Edinburgh, 1878, pp. 435-63; Frame, R., 'The Campaign against the Scots in Munster, 1317' in Frame, Ireland and Britain, pp. 99-112.

48 Sayles, G.O., «The Rebellious First Earl of Desmond», J.A. Watt, J.B.Morrall and F.X. Martin, Medieval Studies presented to Aubrey Gwynn (Dublin, 1961), pp. 20329; O'Brien, A.F., «The Territorial Ambitions of Maurice Fitz Thomas, First Earl of Desmond, with particular reference to the Barony and Manor of Inchiquin, Co. Cork», Proceedings of the Royal Irish Academy, 82 (1982), 59-88; Frame, English Lordship in Ireland, pp. 170-3, 179-82, 187-95, 213-4, 220, 229, 267-70, 286-8. 
of repeated violence into the 1560s. The overlap of the two families' landed and personal interests, especially in east Cork and Waterford, led to fullscale warfare erupting at various times, for example in the late 1390s after the killing of the earl of Ormond's brother by Desmond's kinsmen. ${ }^{49}$ Northeastern Scotland can be described with reference to similar major, aristocratic feuding. From the 1370s the pursuit of greater lordship by Alexander Stewart lord of Badenoch, the son of Robert II, across northern Scotland earned him the epithet of «the wolf» and generated significant conflict, especially with the earls of Moray. After 1390 this conflict had drawn in Clan Donald, the lords of the Isles, as Badenoch's opponents ${ }^{50}$. In the early fifteenth century politics in northern Scotland was dominated by military and political conflict between the lords of the Isles and Badenoch's son, Alexander earl of Mar. Mar may have been the crown's lieutenant, but he acted primarily to protect and safeguard his own interests ${ }^{51}$. The domination of regional politics by these magnates extended to private alliances and attempts to resolve conflict. Marriage alliances were used with limited success to resolve the Ormond-Desmond dispute in the late 1350s and in the 1420s while, in the 1440s, Alexander lord of the Isles and earl of Ross made a bond with the Douglas family, who now held the earldom of Moray ${ }^{52}$. Issues of family were inextricably bound up with regional politics. The failure of the male line or the minority of an heir could transform the status quo. The activities of the first earl of Desmond in Munster were linked to the failure of the Clare lords of Thomond and to the minority of the earl of Ormond after 1338. Between 1398 and 1401 a sequence of deaths in the house of Desmond led to internal family conflict which fuelled the rivalry between James earl of Ormond and his enemies, the Talbots, in the running of the whole lordship of Ireland ${ }^{53}$. In the same way, the death of Alexander earl of Ross in 1402 led to warfare

49 Crooks, P., «Factions, feuds and noble power in the lordship of Ireland», c. 13561496', I.H.S., 140 (2007), pp. 425-58, 453.

50 Boardman, S., «Lordship in the North-East: The Badenoch Stewarts, I, Alexander Earl of Buchan and Lord of Badenoch», Northern Scotland, 16 (1996), 1-30; Grant, A., «The Wolf of Badenoch», in Sellar, W.D.H., Moray, Province and People, Aberdeen, 1992, pp. 143-61.

51 Brown, M., «Regional Lordship in North-East Scotland: The Badenoch Stewarts II: Alexander Stewart Earl of Mar», in Northern Scotland, 16 (1996), pp. 31-54; Boardman, Early Stewart Kings, pp. 256-67.

52 Crooks, «Factions, feuds and noble power», pp. 452-3; O'Brien, «Territorial ambitions», pp. 86-8.

53 Crooks, P., «James the Usurper of Desmond and the origins of the Talbot-Ormond feud», in Duffy, S., Princes, Prelates and Poets in Medieval Ireland (Dublin, 2011), 15984, 168-78. 
between his brother-in-law, Donald lord of the Isles, and Robert duke of Albany, who was guardian of the earl's daughter ${ }^{54}$.

The importance of figures like the earls of Desmond and Ormond, and the Badenoch Stewarts related to their relationships with families of lesser status and resources. For example, the earls of Desmond sought to maintain ties of service or alliance to the leading Irish dynasties of Kerry and Thomond, the MacCarthys and Ó Briens, while a series of written agreements survives between the earls of Ormond and lesser landowners in the southern midlands of Ireland ${ }^{55}$. These included both English and Irish as did 'MacThomas's rout', the infamous following of Maurice first earl of Desmond. Desmond's negative reputation derived from his aggressive pursuit of greater lands and influence across a wide region ${ }^{56}$. The same negative image was applied to Alexander Stewart lord of Badenoch. Alexander of Badenoch and, even more, his son, Alexander earl of Mar, were successful in building up extensive followings. In Mar's case this included both Highland landowners and a group of lowland families from across the north-east. Such followings were not necessarily sources of disruption. Though complaints were made against the quartering of Mar's armed Highland followers (called caterans) on lowland tenants, his reputation did not suffer like that of his father ${ }^{57}$. Perhaps his approach was similar to that of James so-called white earl of Ormond who issued an ordinance regulating the behaviour of his Irish retinues in his lands in $1447^{58}$.

It is easy to overestimate the domination of these magnates in their 'countries'. In both Munster and the Scottish north these retinues were layered and fluid bodies which included bands of professional soldiers, minor dependents and temporary allies. The character of regional societies in Ireland and Scotland owed much to lesser noble families. In Cork, for example, the branches of the Barrys, Roches and MacCarthys played roles

54 Boardman, Early Stewart Kings, pp. 258-60, 289; Brown, «Regional Lordship in NorthEast Scotland», pp. 31-4.

55 Waters, K., "The earls of Desmond and the Irish of south-western Munster», Journal of Medieval History, 32 (2006), pp. 54-68; Empey, C.A., «The Butler Lordship», Journal of the Butler Society, 1 (1970-1), pp. 174-87.

56 Waters, K.A., «The Earls of Desmond in the Fourteenth Century», unpublished PhD thesis, Durham, 2004, pp. 244-77.

57 Brown, «Regional lordship in North-East Scotland», pp. 34-38, 42-44;Boardman, S., «Highland Scots and Anglo-Scottish Warfare, c. 1300-1513», in A. King and D. Simpkin, England and Scotland at War, c.1296-c.1513, Brill, 2012, pp. 231-54, 234 n. 13.

58 Empey, C.A. and Simms, K., «The Ordinances of the White Earl and the problem of Coign in the Later Middle Ages», Proceedings of the Royal Irish Academy, 75 (1975), C, pp. 161-87. 
of local significance and had their counterparts in families like the Grants, Ogilvies and MacKintoshes in north-east Scotland ${ }^{59}$. Men of these names pursued their own objectives in terms of landholding and local leadership, either as individuals or as part of a grouping defined by kinship. However, these goals were pursued within a framework provided by the lordship of greater nobles who could offer protection, patronage and pardons with more immediate value than those provided by the royal government based over a hundred miles away.

Similar concerns shaped relationships between magnates and urban corporations. Even allowing for the exaggeration often found in petitions and narratives, conditions in these regions fostered deep senses of anxiety amongst the elites of cities and towns. In 1375 the mayor and leading men of Waterford were killed by local enemies. In 1388 Cork complained that its suburbs had been burned and on other occasions made clear the need to guard its gates against 'evil neighbours' ${ }^{60}$. Northern Scottish burghs shared these experiences. Inverness, Elgin and Forres were all burned between 1390 and 1430 by forces led by magnates. In 1411 Aberdeen's burgesses provided a contingent at the battle of Harlaw. The provost and many burgesses were killed in a battle subsequently celebrated in the burgh as delivering them from destruction at the hands of Donald of the Isles and his army ${ }^{61}$. The agent of their salvation was Alexander earl of Mar with whom they had links going back over a decade. In 1412 the burgh's council ordered that no burgess should «have lord or lordship other than the king, the duke (Albany, the governor) and the earl of Mar» ${ }^{62}$. In Munster too, urban communities came under the influence of major lords. The earls of Desmond, and Irish lords like the O'Briens and MacCarthys had developed roles as patrons over urban centres in Cork and Limerick, while the earls of Ormond did the same in Waterford ${ }^{63}$.

59 Nicholls, K.W., «The development of lordship in County Cork», in O' Flanagan and Buttimer, Cork, History and Society, pp. 157-212; Cathcart, A., Kinship and Clientage: Highland Clanship 1451-1609, Brill, 2006.

60 Watt, J.A., «The Anglo-Irish colony under strain, 1327-1399», in Cosgrove, A., A New History of Ireland, II, Medieval Ireland, 1169-1534 (Oxford, 1987), pp. 352-96, p. 370.

61 Bower, Scotichronicon, viii, pp. 75, 261; Boardman, S., 'The Burgh and the Realm: Medieval Politics, 1100-1500'; Dennison, Ditchburn and Lynch, Aberdeen before 1800, pp. 203-23; Registrum Episcopatus Moraviensis, 2 vols, Edinburgh, 1837, pp. 381-3.

62 Brown, «Regional lordship in North-East Scotland», p. 35; Ditchburn, D., «The pirate, the policeman and the pantomime star: Aberdeen's alternative economy in the early fifteenth century», Northern Scotland, 12 (1992), pp. 19-34.

63 Watt, «The Anglo-Irish colony under strain, 1327-1399», 370; O'Brien, «Politics, Economy and Society», 114, 122, 131-2. 
There is a direct relationship between the expressions of magnate preeminence which have been discussed and the role played by the government of each realm. For the most part, the approaches of successive Scottish kings and lieutenants and Irish justiciars were based on pragmatic considerations. They recognised the physical distance to the centres of these regions and the need for immediately responsive leadership as key factors. From 1318 the mayor of Cork was released from an obligation to take his oath at the exchequer in Dublin due to the lack of «safe passage» and in 1361 the sheriff was excused attendance at the exchequer for the same reason ${ }^{64}$. By the early fifteenth century real representation from the south-west in parliament seems to have been equally limited. Though the physical distances were more limited to Aberdeen, a similar political gap may have opened up in the later fourteenth-century Scotland between the central government and the north-east. Complaints from the region about lawlessness and violence clearly reached parliament, but evidence of effective responses are hard to discover ${ }^{65}$.

The natural reaction of rulers to these problems of government was to delegate. This was more clearly a feature of the Scottish polity. In 1372 Robert II had appointed his son, Alexander lord of Badenoch, as his lieutenant from the Mounth up to the Pentland Firth with full powers over the exercise of justice $^{66}$. Despite the major problems this grant caused within the region, Badenoch's son, Alexander earl of Mar, was also appointed as lieutenant soon after the battle of Harlaw. A renewal of his commission in 1420 indicates he received powers to hold royal courts and collect royal revenues throughout the north-east ${ }^{67}$. After Mar's death in 1435, a similar role was played by his rival, Alexander lord of the Isles who was justiciar north of the Forth from $1439^{68}$. This sequence suggests the appointment of a magnate as a regional lieutenant was the accepted solution to problems of ruling the northland. In the Irish lordship delegation seems more limited in scale and duration. The earls of Desmond and Ormond were issued commissions to defend their counties and received perpetual grants of local royal offices, like the sergeantships of Kerry, Cork and Waterford which were given to the earls of Desmond ${ }^{69}$.

\footnotetext{
O'Brien, «Politics, Economy and Society», 115-6.

5 Brown, K., et al, Records of the Parliaments of Scotland, St Andrews, 2008 [consulted 10/4/2014]. http://www.rps.ac.uk/, 1366/7/10, 1369/3/5, 1385/4/3.

Boardman, Early Stewart Kings, 72-6.

Brown, «Regional lordship in North-East Scotland», pp. 39-40.

68 Brown, M., «The Great Rupture: Lordship and Politics in North-East Scotland, 14351452», Northern Scotland, 5, 2014, 1-25.

69 O’Brien, «Politics, Economy and Society», 117.
} 
However, both these houses had periods as heads of the royal government during which they were able to preserve and entrench their family interests in the region. It is hard to know whether these spells strengthened bonds between centre and regional society or allowed the further concentration of administration in the hands of the individual magnate lineage.

The only real challenges from the government to the established patterns of regional lordship were the direct and forceful interventions by rulers or their central lieutenants. The progresses into Munster by justiciars like Ralph Ufford in the 1344, Thomas Rokeby in 1355 or John Talbot in 1417 were effectively campaigns which targeted the southern earls ${ }^{70}$. Less confrontational, but of greater prestige were the journeys of princely lieutenants like Clarence or the Mortimers to the province. Significant royal interventions were equally uncommon in northern Scotland. In 1405 and 1411 Robert duke of Albany reached as far as Dingwall in Ross during his competition with Donald of the Isles. David II's northern progresses did represent challenges to magnates from the region. In 1362 David took Kildrummy Castle, imposing a tough settlement on Thomas earl of Mar, while in 1369 at Inverness he received the submission of John lord of the Isles and compelled him to hand over hostages $^{71}$. This event demonstrated the potential authority of the Scottish crown but, as in Ireland, such interventions proved too brief and infrequent to leave a lasting imprint on the politics of the region.

It is possible to develop an understanding of these two regions as sharing similar features in terms of the exercise of royal authority and the significance of competing magnate houses. How does the focus on this regional tier of political society help us to consider the structural and ideological differences between the two lands with which this article began? The issue of ethnic identity is more complex when examined from this regional perspective. Events in north-east Scotland between 1360 and 1450 can be regarded as shaping attitudes on the part of lowland Scots towards their Gaelic-speaking Highland neighbours which regarded them as threatening, alien and lawless. Complaints against Highlanders made during the late 1360s describe them as rebels, comparable to the language deployed in Ireland against disobedient English populations. In the 1380s

70 Frame, R., «The Justiciarship of Ralph Ufford: Warfare and Politics in FourteenthCentury Ireland», in Studia Hibernica, 13 (1973), pp. 7-47; Harbison, S., «William of Windsor, the court party and the administration of Ireland», in Lydon, J, England and Ireland in the Later Middle Ages, Dublin, 1981, pp. 153-74; Crooks, P., "James the Usurper of Desmond and the origins of the Talbot-Ormond feud», pp. 164-5, 174.

${ }_{71}$ Boardman, Early Stewart Kings, p. 288; Bower, Scotichronicon, viii, p. 77; Penman, David II, pp. 274-7, 390-3. 
and beyond the use of the term cateran (equivalent to the Irish kern), meaning a Gaelic soldier, suggests a degree of ethnic identification, though its translation into Latin as malefactor (wrongdoer), indicates that these terms still defined individuals by behaviour, not race ${ }^{72}$. A further shift was linked to the conflict between Albany and the lords of the Isles after 1405. As governor, Albany allowed the heirs of those killed at Harlaw in defence of the patria to inherit without paying relief (succession duty). This concession was used as a reward for service against a foreign enemy. The Insulares, the inhabitants of the Hebridean Islands, were clearly being treated as such, as the English regarded the Irish $^{73}$.

Such treatment supported Albany's political agenda. On the ground, evidence of the identification of sharp boundaries between ethnic groups is harder to find. Around the Highlands the use of the term cateran related to the impact of lordship on wider society. In northern Scotland, as in Munster, a major source of complaint derived from the illegal occupation of property by armed men in the retinues of magnates. Just as the earls of Ormond and Desmond were criticised for such practices, these methods were employed in Scotland by lords regardless of any possible differentiation by ethnic origin $^{74}$. That Alexander earl of Mar, «a leader of caterans», and Alexander lord of the Isles could both act as regional agents can, like the eventual employment of the first earl of Desmond as justiciar of Ireland, be taken to indicate limits to any narrative of government opposition to Gaelicised lordship and society ${ }^{75}$. In the same way it is hard to assign roles based on ethnic labels to the lesser families who comprised these lords' followings. The evidence for the activities of families like the MacKintoshes in Moray or the MacCarthys in Cork does not differentiate them from lineages of AngloFrench descent like the Grants or Barrys. Where written evidence categorised individuals or families according to race or area it often had a direct purpose. When the bishop of Waterford and Lismore, an Englishman, complained against his superior, the archbishop of Cashel, it was by denouncing him for showing favour to his fellow-Irish ${ }^{76}$. This emphasises the continued

72 Boardman, «Lordship in the North-east», pp. 1-5; Reg. Moraviensis, pp. 197-203.

73 Registrum Episcopatus Aberdonensis, 2 vols, Edinburgh, 1845, i, 215; Brown, «Regional lordship in north-east Scotland», 40.

74 Frame, «Lordship beyond the Pale», 9-10.

75 Bower, Scotichronicon, viii, 293; Grant, A., «Scotland's 'Celtic Fringe' in the Late Middle Ages: The Macdonald Lords of the Isles and the Kingdom of Scotland», in R.R. Davies (ed.), The British Isles 1100-1500 Edinburgh, 1988, pp. 118-41; Acts of the Lords of the Isles, 1336-1493, ed. J. Munro and R.W. Munro, Edinburgh, 1986.

76 Otway-Ruthven, History of Medieval Ireland, 361; Cathcart, A., Kinship and Clientage: Highland Clanship 1451-1609, Brill, 2006. 
importance of formal, legal distinctions between races in Ireland but, just like lowland Scottish characterisations of Highlanders as lawless and violent, such examples often have specific motivations and do not fully explain the realities of regional society.

Instead, the examination of regional societies in Munster and northern Scotland suggest a range of similarities within legal and ethnic contexts which, although perhaps converging, remained different. More fundamental in terms of driving change was the impact of personal monarchy in the two realms. In this respect, the 1390s were deeply atypical. In Ireland, the culmination of a series of relatively well-funded interventions by royal officials came in the form of King Richard II's two expeditions to his lordship. In 1394-5 he came with an entourage of nobles and an army of 8,000 men. This unprecedented demonstration of royal power led to submissions to the king by Irish lords who saw Richard as a means of securing recognition of rights and rank. A radical extension of royal authority seemed possible ${ }^{77}$. However, even during Richard's presence it is striking that he never went further into Munster than Waterford and that he relied on Desmond and Ormond to deliver the submission of local Irish lords. One of these, Tadhg MacCarthy, identified himself as being under Desmond's lordship and at odds with Ormond. Open conflict between the earls followed rapidly on Richard's departure ${ }^{78}$.

In the 1390s, Scottish kingship was unable to offer the same impact. However over the longer term, the presence of a king within the realm was the basis for the transformation of Scottish political society. After 1424 James I, James II and James III used the ideological weight of the royal office and its ability to mobilise resources to redraw the rules and make-up of political society. Change came via short periods of conflict but also through longer periods of adaptation to new realities. In north-east Scotland James I treated opposition from the Lord of the Isles, not as a war against an enemy but as rebellion. The arrest of the lord in 1428 and the rout of his army in 1429, reportedly when confronted with the royal standard, expressed the king's monopoly on legitimate authority ${ }^{79}$. In practice James I's efforts disrupted regional structures and it was the reign of his son, James II, which marked lasting shifts. In a reign not short of internal conflict, James II's four northern

77 Johnston, D., «Richard II and the Submissions of Gaelic Ireland», Irish Historical Studies, 22 (1980), pp. 1-20; Lydon, J., «Richard II's expeditions to Ireland», Journal of the Royal Society of Antiquaries of Ireland, 93 (1963), pp. 135-49.

78 Curtis, E., Richard II in Ireland 1394-5 and submissions of the Irish Chiefs, Oxford, 1927, 158.

79 Brown, James I, 93-108, 153-60. 
progresses, in 1447, 1453, 1456 and 1457 accomplished the extension of royal authority without violence. In the first he secured custody of Inverness castle, in the last two he finally confirmed royal possession of the earldoms of Mar and Moray ${ }^{80}$. The royal annexations of Mar, Moray and, in 1476, Ross changed both the role of the crown and the regional elite. The nobility which ran the north in the king's name still contained powerful magnates, like the Gordon earls of Huntly, but service and obligation to the crown was a more clearly defined element in political life than it had been before 1424 . In the wider context, James III's forfeiture of John of the Isles as earl of Ross was less about any conflict with Gaelic Scotland than the extension of the treatment previously given to great nobles like the Albany Stewarts and Black Douglases ${ }^{81}$.

The comparison between northern Scotland and Munster in the midfifteenth century displays the impact of change. Unlike the earls of Mar and Ross, in south-west Ireland the regional power of the earls of Ormond and Desmond remained unaffected by direct royal intervention. The shifts in fortunes, like those which followed the defeat of the earl of Ormond at Pilltown in 1462, related to the regional balance of power. While this fight stemmed from Ormond's involvement in the Wars of the Roses, events in England or even Dublin were a minor element in the political character of the province ${ }^{82}$. This divergence should not be exaggerated. If Scotland as a whole was more integrated politically, the north-east remained a distinctive part of it. For the period before 1450, the adoption of a comparative approach between lands and regions remains an effective way of demonstrating that a central perspective is not inevitably the most revealing starting point for understanding different polities. The power of magnates in Munster and north-east Scotland did not simply fill a vacuum left by weak royal authority. In these countries, as in much of late Medieval Europe, it was these forms of regional lordship which represented both an adaptation to immediate conditions and the most deeply-rooted form of political management ${ }^{83}$.

\footnotetext{
Brown, «The Great Rupture», 18; C.A. McGladdery, James II, Edinburgh, 1990.

N. Macdougall, «Achilles' Heel? The Earldom of Ross, the Lordship of the Isles and the Stewart Kings, 1449-1507», in Cowan, E.J. and McDonald, R.A., Alba, Celtic Scotland in the Middle Ages, East Linton, 2000, pp. 248-75.

82 McCormack, A.M., The Earldom of Desmond, 1463-1583: The Decline and Crisis of a Feudal Lordship, Dublin, 2005, 40, 58-61; Otway-Ruthven, History of Medieval Ireland, 389-92.

83 Watts, The Making of Polities, 275-6.
} 